\title{
Perception of the parents of children with intestinal stoma regarding the nursing orientations
}

\section{Percepção dos pais de crianças com estomia intestinal a respeito das orientações de enfermagem}

\section{Percepción de los padres de niños con estomia intestinal respecto de las orientaciones de enfermería}

Elisa Maria Bezerra Maia ${ }^{1, *}$, Gisela Maria Assis ${ }^{1}$

ORCID IDS
Maia EMB (D) https://orcid.org/0000-0002-1768-1928
Assis GM (D) https://orcid.org/0000-0001-6343-8075
HOW TO CITE

Maia EMB, Assis GM. Perception of the parents of children with intestinal stoma regarding the nursing orientations. ESTIMA, Braz. J. Enterostomal Ther., 17: e0819. https://doi.org/10.30886/estima. v17.663 IN

\begin{abstract}
Objective:Thepresentstudyaimedtoidentifytheperception oftheparents ofchildrenwithintestinaleliminationstomaabouttheguidelines received by the health team during hospitalization for their preparation. Methods: This is a cross-sectional, qualitative and quantitative study. Data collector occurred in the pediatric surgery ward of a university hospital through a semi-structured interview, recorded and composed of open and closed questions. Results: Nine parents of children with intestinal elimination stoma were followed up by the pediatric surgery team. Subsequently, it was submitted to the simple and categorical statistical analysis of Bardin. Regarding the main complications, the presence of dermatitis was indicated by $100 \%$ of the sample and the fungal infections followed by prolapse by $44.4 \%$. The study showed that the lack of knowledge results in complications and insecurity. The support network is one of the resources used to search for information. A manual with guidelines was pointed out as a strategy for home care. Conclusion: Despite the failures in the guiding and supporting parents of children with a stoma, the feedbacks to help with changes and suggestions for valid strategies were important.
\end{abstract}

DESCRIPTORS: Health education; Colostomy; Nursing; Stomatherapy.

1.Universidade Federal do Paraná - Complexo Hospital de Clínicas - Comissão de Cuidados com a Pele - Curitiba/PR - Brazil

*Correspondence author: elisamaia13@hotmail.com

Received: Nov. 032018 | Accepted: May 022019 


\section{RESUMO}

Objetivo: O presente estudo teve o objetivo de identificar a percepção dos pais de crianças com estomia de eliminação intestinal acerca das orientações recebidas pela equipe de saúde durante a hospitalização para sua confecção. Métodos: Trata-se de estudo transversal, qualiquantitativo. A coleta de dados ocorreu na enfermaria de cirurgia pediátrica de um hospital universitário por meio de entrevista semiestruturada, gravada e composta por perguntas abertas e fechadas. Resultados: Participaram da pesquisa nove pais de crianças com estomia de eliminação intestinal em acompanhamento pela equipe de cirurgia pediátrica. Posteriormente, foram submetidos à análise estatística simples e categorial temática de Bardin. Com relação às principais complicações, a presença de dermatite foi apontada por $100 \%$ da amostra e as infecções fúngicas seguidas de prolapso por 44,4\%. O estudo demonstrou que a falta de conhecimento resulta em complicações e insegurança. A rede de apoio constitui um dos recursos utilizados para a busca de informação. Um manual com orientações foi apontado como estratégia para o cuidado no domicílio. Conclusão: Apesar das falhas na orientação e do apoio aos pais de crianças com estomia, os feedbacks para auxílio nas mudanças e sugestões de estratégias válidas foram importantes.

DESCRITORES: Educação em saúde; Colostomia; Enfermagem; Estomaterapia.

\section{RESUMEN}

Objetivo: El presente estudio tuvo el objetivo de identificar la percepción de los padres de niños con estomia de eliminación intestinal acerca de las orientaciones recibidas por el equipo de salud durante la hospitalización para su confección. Métodos: Se trata de un estudio transversal, cualiquantitativo. La recolección de datos ocurrió en la enfermería de cirugía pediátrica de un hospital universitario por medio de entrevista semiestructurada, grabada y compuesta por preguntas abiertas y cerradas. Resultados: Participaron de la investigación nueve padres de niños con estomia de eliminación intestinal en seguimiento por el equipo de cirugía pediátrica. Posteriormente, fueron sometidos al análisis estadístico simple y categorial temático de Bardin. Con respecto a las principales complicaciones, la presencia de dermatitis fue apuntada por el 100\% de la muestra y las infecciones fúngicas seguidas de prolapso por el 44,4\%. El estudio demostró que la falta de conocimiento resulta en complicaciones e inseguridad. La red de apoyo constituye uno de los recursos utilizados para la búsqueda de información. Un manual con orientaciones fue apuntado como estrategia para el cuidado en el domicilio. Conclusión: A pesar de las fallas en la orientación y el apoyo a los padres de niños con estomia, los feedbacks para ayudar en los cambios y sugerencias de estrategias válidas fueron importantes.

DESCRIPTORES: Educación en salud; Colostomía; Enfermería; Estomaterapia.

\section{INTRODUCTION}

The stoma is considered a surgical intervention with the function of facilitating the communication between an internal organ and the external environment ${ }^{1}$. When in intestinal areas, it can be made in both the small intestine (ileostomy) and the large intestine (colostomy), which connects to the abdominal wall through a surgical incision in order to allow intestinal emptying ${ }^{2}$.

The presence of a stoma can generate sequels and deficits in the general state of health, necessitating continuous care. When this condition occurs in childhood, care may be more intense, considering the anxieties and fears of the child and its relatives ${ }^{3}$.

The main indications for childhood colostomy are anorectal anomalies, congenital megacolon, colonic and rectal atresias, inflammatory diseases, perineal trauma, necrotizing enterocolitis and pelviperineal infections for the purpose of decompression, protection, and evacuation ${ }^{2}$.

Proper preparation of a stoma is essential to provide quality of life (QOL) to the child ${ }^{4}$. In addition, the therapeutic care that involves these children should be oriented and guided by a multidisciplinary team so that the family feels more confident in dealing with the challenges that such condition provides ${ }^{1,3,5}$.

To this end, the guidelines should be enlightening regarding the definition of a stoma, what it serves, how to handle and what will be the routine of daily care for this child, always bringing the positives and benefits ${ }^{1,5}$. It is important to allow the child and its family to manipulate the materials it will use to prevent surprises in the immediate postoperative period ${ }^{3}$.

There is a shortage of references that indicate specific guidelines on the discharge of the child with stoma ${ }^{3}$. Considering that it is the responsibility of the nurse to interact and plan with the multidisciplinary team and the family in conducting discharge guidelines, from the moment of admission to the start of the stoma to the discharge of the child to home ${ }^{5}$, it is expected that this professional will also act in the development of quality scientific material in this area. 
Some of the complications of stomization may be the formation of hernia, local infections, retractions, stenosis, prolapses, and intestinal obstruction ${ }^{6}$. Care to avoid some of these problems includes local cleaning, proper use of collector bags, dietary control to avoid the alteration of $\mathrm{pH}$ feces, and treating peristaltic dermatitis and local secondary infections ${ }^{2}$.

Considering the difficulties of acceptance and care of the child with a stoma, pointed out as a consequence of the nursing care planning gaps and the orientation during the operative process, it is necessary to expand the investigations related to the experience of the parents on the subject, with that it develop skills to improve home care.

This study aimed to identify the perception of the parents of children with intestinal elimination stoma about the guidelines received during hospitalization for its preparation.

\section{METHODS}

This is an exploratory and descriptive cross-sectional study with a qualitative approach performed at a university hospital in the southern region of Brazil. The study was approved by the Committee of Ethics in Research with Human Beings under opinion 2062061/2017.

To participate in the study, the sample was composed of parents of children aged between zero and 11 years, with intestinal elimination stoma made between January 2014 and December 2016, who were followed up by the hospital and received direct care and domicile performed by the parents. The data were collected between July and December of 2017, through audio-recorded interviews performed at the time before or after the outpatient follow-up consultations of the pediatric surgery team. It was used as a semistructured instrument, built by the researchers, based on the literature consulted. To characterize the sample, the variables gender, age, clinical diagnosis, types of stoma, guidelines received by the multidisciplinary team in the pre and postoperative period, complications and demarcation of the stoma site were investigated. For the qualitative step, the following questions were used: "How was the experience of taking care of your child with a stoma?" and "What could the hospital do to adapt the parents of children with a stoma?". The quantitative data were submitted to simple statistical analysis and the qualitative data were analyzed using Bardin's thematic categorical analysis technique, which was performed by the analytical steps: pre-analysis; exploration of the material; and treatment of results obtained and interpretation ${ }^{7}$.

In the pre-analysis stage, the researcher made the complete transcription of the interviews, the floating reading to capture the main ideas contained and the elaboration of the indicators of the text fragments related to the object of study. In the exploration of the material, the data were codified and grouped into thematic categories, searching for the connections and integrations between the raw data. Finally, in the data processing and analysis stage, inferences and interpretations were made, based on the meanings and knowledge of the messages issued by the participants.

To identify the participants, the letter "P" followed by Arabic numbers from one to nine (P1,P2,P3...) corresponding to the chronological order of the meetings was adopted.

\section{RESULTS AND DISCUSSION}

Parents of nine children were interviewed, among them four mothers, two fathers and three mother and father couples. According to Table 1 , there was a higher prevalence of male children up to two years of age with clinical diagnosis, mostly related to congenital anomalies or malformations, with a terminal colostomy.

Regarding the guidelines received by the parents, seven participants reported receiving guidance regarding the surgical technique prior to performing the surgery and two were not clarified about the procedure prior to the preparation of the stoma. After surgery, all parents were instructed regarding the surgical procedure.

With regard to the number of parents oriented in direct care to the stoma, it was observed that $88 \%$ of the sample was not informed about the collector equipment and adjuvants existing in the market and used as a resource for effluent collector and treatment of the stoma, $44.4 \%$ did not receive orientation regarding the adaptation of the collector equipment to the child (frequency of exchange of bag collector equipment) and 33.3\% regarding emptying and sanitizing. Another important point that was evident as a failure in the guidelines (88.8\%) were the activities allowed to children who have some type of intestinal elimination stoma, considering the possibility of serious complications related to them (Table 2).

Table 2 also shows that dermatitis (100\%), fungal infections (44.4\%) and prolapse (44.4\%) were the main 
Table 1. Characterization of the study participants' children regarding gender, age, clinical diagnosis and type of stoma. Curitiba, state of Parana, 2017.

\begin{tabular}{|c|c|}
\hline Characteristics & $\mathrm{n}(\%)$ \\
\hline \multicolumn{2}{|l|}{ Gender } \\
\hline Female & $3(33.3)$ \\
\hline Male & $6(66.7)$ \\
\hline \multicolumn{2}{|l|}{ Age (years) } \\
\hline$<1$ & $3(33.3)$ \\
\hline 1 & $2(22.2)$ \\
\hline 2 & $2(22.2)$ \\
\hline 3 & $1(11.1)$ \\
\hline 11 & $1(11.1)$ \\
\hline \multicolumn{2}{|l|}{ Clinical diagnosis } \\
\hline $\begin{array}{l}\text { P77 Necrotizing enterocolitis of the fetus and } \\
\text { newborn }\end{array}$ & $1(11.1)$ \\
\hline Q42.3 Anal imperforation & $2(22.2)$ \\
\hline $\begin{array}{l}\text { Q42.8 Atresia and congenital stenosis of } \\
\text { other parts of the colon }\end{array}$ & $2(22.2)$ \\
\hline Q43.1 Congenital Megacolon & $1(11.1)$ \\
\hline Q43.7 Sewer persistence & $1(11.1)$ \\
\hline $\begin{array}{l}\text { T81.2 Accidental perforation and laceration } \\
\text { during procedure not elsewhere classified } \\
\text { (bowel) }\end{array}$ & $2(22.2)$ \\
\hline \multicolumn{2}{|l|}{ Type os Stoma } \\
\hline Colostomy terminal & $5(55.6)$ \\
\hline Double mouth colostomy & $2(22.2)$ \\
\hline Ileostomy & $2(22.2)$ \\
\hline
\end{tabular}

complications observed with the stoma and peristomal skin. In a study that verified the occurrence of complications related to the manufacture of the stoma, it was observed that $15.25 \%$ presented complications, being $44.45 \%$ stenosis, $44.45 \%$ prolapses and $11.11 \%$ peristome dermatitis ${ }^{8}$. It was observed a great difference between the two studies, mainly in relation to the number of dermatitides, which leads to the reflection of the determinants of this reality. Such complication may be directly related to the failure of the guidelines on care with the stoma, generate insecurity and motivate the search for information in unsafe sources, a fact pointed out by the participants of this study.

All parents reported being the first time they had contact with intestinal elimination stoma and this fact reinforces the necessity to be guided and clarified about the process, so that, in addition to participating actively, it could follow and claim actions at all stages of the process of confection.
Table 2. Orientations received by parents and stoma and peristomal complications of children attending a university hospital in the southern region of Brazil. Curitiba, state of Parana, 2017.

\begin{tabular}{|c|c|}
\hline Variables & $\mathrm{n}(\%)$ \\
\hline \multicolumn{2}{|l|}{ Pre and post-surgical guidelines } \\
\hline Surgical technique & $9(100)$ \\
\hline Equipment and adjuvants & $2(22.2)$ \\
\hline Evaluation of the stoma and peristomal skin & $7(77.8)$ \\
\hline Cutout of the collector bag & $5(55.6)$ \\
\hline Frequency of exchange of the collector bag & $6(66.7)$ \\
\hline Emptying the collector bag & $5(55.6)$ \\
\hline Permitted and contraindicated activities & $2(22.2)$ \\
\hline \multicolumn{2}{|l|}{ Complications with a stoma and peristomal skin } \\
\hline Dermatitis & $9(100)$ \\
\hline Fungal infections & $4(44.4)$ \\
\hline Prolapse & $4(44.4)$ \\
\hline Retraction & $1(11.1)$ \\
\hline Occlusion & $1(11.1)$ \\
\hline Mucocutaneous dehiscence & $1(11.1)$ \\
\hline Ischemia & $1(11.1)$ \\
\hline Hernia & $2(22.2)$ \\
\hline
\end{tabular}

The stomatotherapist or trained nurse can assist in the demarcation of the stoma site, indicating, together with the family, the best place to be externalized in the abdominal wall. The demarcation can occur the day before or shortly before the surgical procedure, delimiting the appropriate region to better adapt the collector equipment with a view to comfort, better family and social interaction, with daily activities without damage 9 .

The following thematic categories resulting from the analysis of the interviews with the participants will be presented, these being: lack of knowledge can result in complications with the stoma and peristomal skin; ignorance causes insecurity and fear to care for the child with the stoma at home; the role of the support network in the home care of the child with the stoma; knowledge generates safety to take care of the child with the stoma; strategies that could contribute to the care of the child with stoma at home.

\section{Lack of knowledge can result in complications with the stoma and peristomal skin}

Participants expressed that they did not receive enough guidelines to care for the child with a home stoma, or even 
how to prevent serious complications such as dermatitis and prolapse:

"He did prolapse and fungal dermatitis and I received no guidance." (P6)

"But now it gets big and purple (the stoma), sometimes it gets kind of black, I've never had guidance [...] no one told me what could happen and bleed so easily.” (P8)

"The bag is open there (peristomal skin), there it is hurting his skin, it's getting that redness [...] I take care of it, I do not bring it here anymore (hospital) because I come and spend the same thing I spend at home.” (P3)

As noted, most parents reported that they had not been correctly instructed about direct care of the stoma, which may have resulted in at least one stoma or peristomal complication of the present study. In this sense, other authors report that the lack of information about the stoma entailed complications followed by complaints about the management of health care and the incipient knowledge on the subject by the service professionals, which led to undue conduct and its consequences, such as the use of inadequate collector equipment, peristomal skin maceration, irritations, and redness ${ }^{10}$.

As an aggravating factor, it can be seen in the current scenario that scientific publications that deal with the pediatric scenario of the intestinal stoma are scarce. However, an integrative review with adults regarding the psychological aspects of patients with intestinal stoma presented the importance of preoperative guidance to reduce postoperative complications, contributing to the adaptation and coping of stomization ${ }^{11}$.

\section{Unknowing causes insecurity and fear to care for the child with an at home stoma}

Many participants reported feelings of insecurity and fear for the direct care of the stoma. They emphasized that the fact that they had no previous knowledge on the subject led them to feel unprepared and incapacitated in the care and management of the situation:

"We had never been through it, it was a thump, use a colostomy bag, what is it? [...] One day I came home crying, my God I will not know how to take care of this child, I will not get [...].”(P3)

"I could not get my hands on the colostomy, I was afraid to hurt ...I took him home and I did not know how to bathe, it was one of my problems, I did not know how to bathe a child with an open wound in the belly.” (P6)

"We never had psychological support here, I think it was what we lacked, it was a new thing, we did not know how to deal and what to expect." (P9)

It is also noticed during the listening to the parents, the lack of security, conversation and exchange with the multidisciplinary team, generating feelings of anguish and abandonment, when the reported is the lack of someone who understands, guides and supports. Thus, in addition to being very exhausting, the desire of the parents is that the child receives treatment and return soon to home and family life because there will be more understanding ${ }^{12}$.

The lack of resources and training of the professional team, together with the lack of information received, culminates not only in feelings of fear, uncertainty, and helplessness, but also brings problems to the child with the stoma ${ }^{10}$.

In the state of Rio Grande do Sul (RS), participants from a support group to the person with stoma cite the lack of systematization of care and guidelines for hospital discharge and realized that there is insufficient specific knowledge about care for intestinal of professionals, which hampers the learning process and postpones adaptation to the new reality ${ }^{13}$.

\section{The role of the support network in the home care of children with a stoma}

The participants demonstrated, in your speech, that, given the lack of information about how to take care of their children's stoma, they were led to the search for alternative sources of information, such as the internet, parents of other children, associations, and nurses, as shown in the following sections:

"The mother of a patient helped me after I went home, a lot of things she was telling me how I did it and it was better."(P2)

"[...] I went to the association, they gave a class to us and explained it right, there they have more time, here they do not have much time." (P3) 
"We've even had to follow about colostomy on Facebook, there's a lot of doubt we need to get into [...]” (P9)

The search for alternative sources contributed to the parents' reduction of the anxiety generated by not being able to take care of and to coexist with people who had similar situations.

It is emphasized that social relations have a relevant role in the life of the person with the stoma. Social support is a process that involves relationships and facilitates moderation and balance in situations of stress and anxiety. A study realized in relation to the social support received found that social support would have been "sufficient" in $49.5 \%$ of the cases and "insufficient" in another $36.5 \%$ and that there was no association of the result with the socioeconomic profile ${ }^{14}$.

The results regarding the search for support networks and alternative learning strategies in the face of the failure of the guidelines for hospital discharge were also found in a study realized in a support group for the person with stoma with adult participants who reported the lack of guidelines, prolonging the process of learning and leading to the necessity to search for other ways to meet the demands of stomization. These participants cite having learned by reading guidelines on the use of collector equipment in the packaging, searching the internet or alone in practice ${ }^{13}$.

On the other hand, it should be emphasized that there is a risk related to the lack of scientificity of some sources mentioned by the participants that can lead to inappropriate behaviors that will result in complications for the child.

In view of the above, we can see a cyclical effect of complications caused by the failure of the care guidelines to the child with the stoma during hospitalization. With a lack of guidance, parents expose children to inadequate behaviors that lead to complications. These, therefore, tend to intensify insecurity and lead parents to seek alternative sources of guidance.

\section{Knowledge generates safety to care for the child with a stoma}

Some participants reported believing that having received more information about care with the stoma could have prevented suffering and allowed them to have more peace and security to care for their children.

"If we had more information we would not go through all this." (P3)
"Everything that is the first time, first situation, is an impact for everyone; after you get to deal with the colostomy becomes easier." (P4)

"In fact, their directions were good, which they taught us. We did not know anything about a colostomy." (P7)

It was possible to observe that the interviewed parents consider that the knowledge and experience acquired, by alternative means or by the very experience of care, tend to mitigate negative feelings such as insecurity, fear, and impotence.

The current literature reinforces the findings of the study, citing that the technical orientation of the care of the stoma has the capacity to reduce negative feelings, but there is still a necessity to include the emotional, social, cultural and spiritual aspects in the perioperative care, which should contemplate the teaching about surgery and its consequences, involving family members and making possible effective participation ${ }^{11}$.

\section{Strategies that could contribute to the care of the child with a stoma at home}

The sample studied was questioned as to how they would like to receive the guidelines regarding the care of their children. It was observed, in the speeches, the richness of content in the suggestions regarding strategies that the service could adopt to better conduct these guidelines. Among the possibilities, illustrative books, folders, and videos were cited, as well as specialized professionals to review the necessary guidelines:

"I think in a little book because at least you would take it home and any questions you had would look.” (P1)

"I could have videos explaining how to take care or a book showing care with the stoma. Here at the hospital, it should have a person specialized for the stoma, because there are many nurses who do not even know what stoma is and how to care for it, $[. .$.$] better orientate people and something$ that they can take home." (P2)

"I think there should be space for these mothers because only those who have passed will know how another mother will help." (P6)

It was observed that most of the participants suggested a printed guide, either in the form of a folder or a manual, 
demonstrating their lack of reliable support material to mitigate their doubts in the face of difficult care.

Most of the textbooks currently available describe adult colostomy care, few of which address the needs of children and their parents. A study realized in India in a tertiary-level network using audiovisual educational aids in teaching parents of children with colostomy generated an increase in knowledge indexes immediately after the technique performed. It also showed a significant improvement in knowledge scores and skills with the guidelines provided in the hospital environment ${ }^{15}$.

Patients evaluated in other studies believe that the health system should be more focused on the training of stomatotherapist nurses, considering them reference in the healthcare process of people with a stoma. The interviewees also indicated the necessity for improvements to the system, the insertion of the specialty in all phases of health care, especially in the public health centers, where people with stoma receive the first post-hospital care ${ }^{10}$.

A study realized in Santa Maria (RS), in order to know the perceptions of participants of a support group for people with colostomy on the use of an educational video, obtained as a result that the presented technology was considered valid as a complementary strategy for education in the health of these people and their families. One of the participants in the cited study reports that if the video presented in the association was still in the hospital where the stoma was built, they would already be more strengthened ${ }^{13}$. This research demonstrates the consistency and applicability of the suggestion of the use of the video in the training process for care with the stoma presented by two participating families.

It is worth mentioning that, during the elaboration of this article, the institution where the data collector was performed was already in the process of remodeling the assistance provided to this population, in response to the presented results. A guideline manual for parents of children with an intestinal stoma is under development, based on the participants'suggestions and current literature. In addition, preand postoperative care begins to be performed by the institution's specialist nurses in partnership with the multidisciplinary team.

\section{CONCLUSION}

During the study, it was identified a considerable failure in the orientation and support to the parents of children with a stoma in the studied institution. The consequences of these knowledge gaps are complications related to wrong conducts, feelings of fear, and parents' inability to care for their child.

The support network acted in a positive and negative way, considering the mistakes and knowledge gaps for the home care of the child with the stoma since often the parents used popular tools without theoretical foundation.

The size of the sample was limited, but it was determined by the number of surgeries that occurred during this triennium, taking into consideration the inclusion criteria, such as the home care of the child with the stoma and the current outpatient follow-up at the institution, which ended up limiting the quantitative analysis and prevented statistical treatment, presenting only descriptive statistics, making the association among the variables unfeasible.

The study also demonstrated the importance of feedback to aid in the changes and suggestions of valid strategies that could contribute to the implementation of a flow of care and guidelines for the care of children with a stoma.

In view of the responsibility of hospital institutions and professionals regarding the guidelines for the discharge of the child with stoma, it is necessary to assume the roles of the network as a whole, giving support to the family, an important part in the direct relation to the care process, in order to make it fit and able to perform all the activities related to direct care of this child, allowing improvements in their QOL and also the family and community in which they are inserted.

Regarding the limitations of this research, it was possible to perceive that the literature that addresses direct care with the stoma and necessary guidelines for hospital discharge in pediatrics is quite scarce, which brings us the necessity to expand studies in this area.

For the future, it is suggested multicenter studies with larger samples and prospective researches that test the effectiveness of systematic and distinct methods in reducing the complications of children's stoma and peristomes, as well as the attenuation of feelings of distress, fear and parents' insecurity in the care of these children.

\section{AUTHORS' CONTRIBUTION}

Conceptualization, Maia EMB and Assis GM; Methodology, Maia EMB and Assis GM; Research, Maia EMB; Writing - First version, Maia EMB; Writing - Review \& Editing,Maia EMB and Assis GM; Supervision, Assis GM. 


\section{REFERENCES}

1. Melo MC, Kamada I. O papel da família no cuidado à criança com estoma intestinal: uma revisão narrativa. ESTIMA, Braz J Enterostomal Ther. 2015;13(3):43-9.

2. Paula MAB, Paula PR, Cesaretti IUR, organizadores. Estomaterapia em foco e o cuidado especializado. São Caetano do Sul: Yendis; 2014.

3. Zacarin CFL, Alvarenga WA, Souza ROD, Borges DCS, Dupas G. Vulnerabilidade da família de crianças com estomia intestinal. Revista Eletrônica de Enfermagem. 2014;16(2):426-33. https://doi.org/ 0.5216/ree.v16i2.26639

4. Monteiro SNC, Melo MC, Kamada I, Silva AL. Caracterização de cuidadores de crianças e adolescentes estomizados atendidos em serviço de reabilitação. ESTIMA, Braz J Enterostomal Ther. 2016;14(2):76-83. https://doi. org/10.5327/z1806-3144201600020005

5. Diniz IV, Matos SDO, Brito KKG, Andrade SSC, Oliveira SHS, Oliveira MJGO. Nursing care applied to children with an ostomy arising from Hirschsprung's disease. Rev enferm UFPE on line. 2016; 10(3): 1119-26. https://doi.org/10.5205/ reuol.8702-76273-4-SM.1003201623

6. Almeida EJ de, Silva AL da. Caracterização do perfil epidemiológico dos estomizados em hospitais da Secretaria de Estado de Saúde do Distrito Federal. ESTIMA, Braz J Enterostomal Ther. 2015;13(1):11-6. https://doi. org/10.5327/Z1806-3144201500010004

7. Bardin L. Análise de conteúdo. Trad. Reta LA, Pinheiro A. São Paulo: Edições 70; 2016.

8. Costa ECL da, Vale DS do, Luz MHBA. Perfi das crianças estomizadas em um hospital público de Teresina, Piauí. ESTIMA, Braz J Enterostomal Ther. 2016;14(4):169-74. https://doi.org/10.5327/Z18063144201600040003
9. Silva JC, Borsatto AZ, Teixeira ER, Umpiérrez AF. Demarcação abdominal por enfermeira estomoterapêuta. Enfermería (Montev.). 2017;6(1):12-8. https://doi.org/10.22235/ech. v6i1.1365

Nieves CB de las, Díaz CC, Celdrán-Mañas M, Morales-Asencio JM, Hernández-Zambrano SM, Hueso-Montoro C. Percepção de pacientes ostomizados sobre os cuidados de saúde recebidos. Rev Latino-Am Enfermagem. 2017;25: e2961. https://doi. org/10.1590/1518-8345.2059.2961

10. Silva NM, Santos MA dos, Rosado SR, Galvão CM, Sonobe HM. Aspectos psicológicos de pacientes estomizados intestinais: revisão integrativa. Rev Latino-Am Enfermagem. 2017;25:e2950. 8345.2231 .2950

https://doi.org/10.1590/1518-

11. Sélos PR, Costa PCP, Toledo VP. Vivendo em casa de apoio durante o tratamento do câncer infantil: percepções maternas. Rev enferm UFPE on line. 2014;8(6):1474-81.

12. Dalmolin A, Girardon-Perlini NMO, Coppetti LC, Rossato GC, Gomes JS, Silva MEN. Vídeo educativo como recurso para educação em saúde a pessoas com colostomia e familiares. Rev Gaúcha Enferm. 2016;37(Espec):e68373. https://doi. org/10.1590/1983-1447.2016.esp.68373

13. Reis FF dos, Carvalho AAS, Santos CSB, Rodrigues VMCP. Percepção sobre o apoio social do homem colostomizado na região norte de Portugal. Esc Anna Nery. 2014;18(4):5707. https://doi.org/10.5935/1414-8145.20140081

14. Dabas H, Sharma KK, Joshi P, Agarwala S. Video teaching program on management of colostomy: Evaluation of its impact on caregivers. I Indian Assoc Pediatr Surg. 2016;21(2):54-6. $\quad$ https://doi.org/10.4103/09719261.176933 